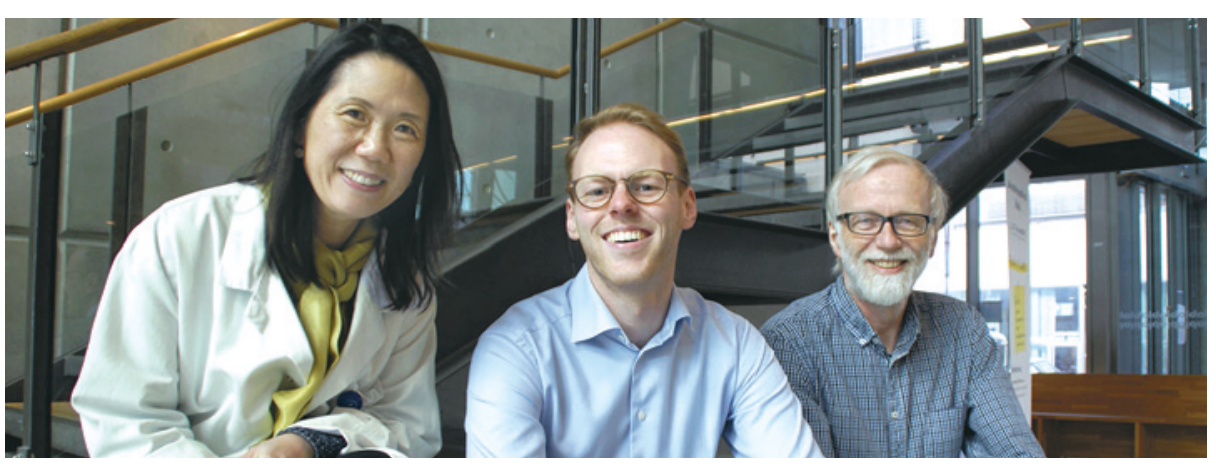

Fra venstre: Hong Yan Dai, Even Holth Rustad, Anders Waage. Foto: Hanne Strypet, Det medisinske fakultet, Norges teknisk-naturvitenskapelige universitet.

MIN FØRSTE PUBLIKASJON

\section{Målrettet kreftbehandling ved myelomatose?}

BRAF V600E-mutasjon ved myelomatose kan behandles med spesifikke medikamentelle hemmere, men mutasjonen finnes kun hos et fåtall

pasienter med myelomatose.

Det er knyttet store forventninger til målrettet kreftbehandling basert på identifisering av drivermutasjoner i svulsten, slik at pasienten kan behandles med spesifikke hemmere av det endrede proteinet. BRAF V600E-mutasjonen, som blant annet finnes hos halvparten av pasienter med malignt melanom, er et eksempel på en slik mutasjon som kan hemmes medikamentelt. Forutsetningen for at behandlingen skal fungere er at den aktuelle mutasjonen er til stede $i$ en stor andel av kreftcellene. I en norsk studie, utgått fra Norges teknisk-vitenskapelige universitet, har man undersøkt forekomst og betydning av BRAF V600E-mutasjon hos pasienter med myelomatose (1). Dette er førsteforfatter Even Holth Rustads første publikasjon.

BRAF V600E-mutasjon ble funnet hos 11 av $209(5,3 \%)$ pasienter med myelomatose. Denne andelen er i samsvar med tidligere studier. Mutasjonen ble påvist i benmargsbiopsier med mutasjonsspesifikk polymerasekjedereaksjon og bekreftet med minst én annen metode. Undersøkelse med immunhistokjemi viste at mutert BRAF var uttrykt $i$ en varierende andel av kreftcellene, men hos bare tre pasienter $(1,4 \%)$ var mutasjonen til stede i over $75 \%$ av kreftcellene.

- Dette er den andre studien som har koblet mutasjonsstatus og kliniske pasientdata, sier Rustad, som er artikkelens førsteforfatter.

Den første studien viste at myelomatosepasienter med BRAF V600E-mutasjonen hadde svært aggressiv sykdom og kort overlevelse sammenliknet med pasienter uten denne mutasjonen.

- I vår studie, derimot, responderte de mutasjonspositive pasientene godt på konvensjonell behandling og hadde lengre over- levelse enn kontrollgruppen, men forskjellen var ikke statistisk signifikant. Vår studie tyder på at det ikke er sammenheng mellom BRAF V600E-mutasjon og klinisk fenotype hos pasienter med myelomatose. Bare tre av pasientene hadde stor nok andel celler med mutasjonen til å gi teoretisk grunnlag for målrettet behandling, og disse responderte godt på konvensjonell behandling. Hvis BRAF-hemmere skal tilbys som behandling til utvalgte pasienter med myelomatose, bør det være i kombinasjon med konvensjonell behandling, sier Rustad.

\section{Forskerlinjestudent \\ og doktorgradsarbeid}

Artikkelens førsteforfatter er forskerlinjestudent ved K.G. Jebsen - senter for myelomforskning ved Norges teknisk-naturvitenskapelige universitet. Studien inngår i hans doktorgradsarbeid om påvisning og betydning av kreftspesifikke mutasjoner ved myelomatose. Hovedveileder og biveileder er Anders Waage og Anders Sundan. Studien er et samarbeid med Hong Yan Dai, Haakon Hov og Harald Aarset, som har stått for store deler av analysene. DNA-sekvensering er gjort i samarbeid med Norwegian Cancer Genomics Consortium (NCGC), som er et nasjonalt samarbeid om kreftgenetikk, ledet av Ola Myklebost ved Universitetet i Oslo.

\section{Lise Mørkved Helsingen}

Tidsskriftet

\section{Litteratur}

1. Rustad EH, Dai HY, Hov H et al. BRAF V600E mutation in early-stage multiple myeloma: good response to broad acting drugs and no relation to prognosis. Blood Cancer J. E-publisert 20.3.2015.
Ordforklaringer

Myelomatose (beinmargskreft): Kreftsykdom som skyldes opphopning av monoklonale plasmaceller i beinmargen. Rammer ca. 380 mennesker hvert år i Norge.

Subklon: En undergruppe kreftceller med genetiske fellestrekk som skiller dem fra andre kreftceller med samme opphav. Subkloner vokser frem som greiner på et tre.

BRAF: Tyrosinkinase som inngår i RAS/RAF/ MEK/ERK-signalveien. Aktiverende mutasjoner i BRAF vil ofte øke celledelingen og gjøre den mer uavhengig av kontrollerende signaler. Det kan være et steg på veien til en kreftcelle. 